\title{
ANALISIS RASIO PROFITABILITAS PADA USAHA EKONOMI DESA SIMPAN PINJAM (UED-SP) DESA KEMBUNG LUAR DITINJAU DARI PERSPEKTIF SYARIAH
}

\author{
Dariana \\ Sekolah Tinggi Ilmu Ekonomi (STIE) Syariah Bengkalis \\ Email: dariana.bengkalis72@gmail.com
}

\begin{abstract}
ABSTRAK
Penelitian ini dilakukan untuk melihat Rasio Profitabilitas pada Usaha Ekonomi Desa Simpan Pinjam (UED-SP) Desa Kembung Luar. Tujuan penelitian ini adalah untuk mengetahui Rasio Profitabilitas pada Usaha Ekonomi Desa Simpan Pinjam (UED-SP) Desa Kembung Luar. Dan Rasio Profitabilitas pada Usaha Ekonomi Desa Simpan Pinjam (UED-SP) Desa Kembung Luar menurut perspektif Syariah. Penelitian ini dilaksanakan pada Usaha Ekonomi Desa Simpan Pinjam (UED-SP) Desa Kembung Luar. Subjek dari penelitian ini adalah Usaha Ekonomi Desa Simpan Pinjam (UED-SP) Desa Kembung Luar dan objek penelitian Rasio Profitabilitas. Analisis data yang digunakan dalam penelitian ini analisis deskriptif kualitatif yaitu menggambarkan hasil penelitian dengan menelaah data yang diperoleh dari perusahaan kemudian dibandingkan dengan berbagai teori yang mendukung masalah penelitian. Hasil penelitian menunjukkan bahwa perhitungan Return On Invesment tahun 2016-2018 ROI mengalami penurunan karena perputaran aset dan laba bersih dalam satu tahun menurun. Hal ini menunjukkan kemampuan UED-SP dalam menghasilkan laba bersih dari aset belum maksimal. Tahun 2016-2018 mengalami peningkatan karena laba yang dihasilkan pada tahun 2016-2018 meningkat. Begitu juga dari hasil perhitungan Return On Equity, bahwa pada UED ini dalam mengelola modal dalam menghasilkan keuntungan netto mengalami penurunan pada tahun 2016-2017 dan mengalami peningkatan di tahun 2017-2018. Rasio profitabilitas pada UED-SP Desa Kembung Luar tidak sesuai dengan prinsip syariah karena terdapat bunga. Ketidaksesuaian tersebut disesuaikan firman Allah dalam QS. Ali-'Imran ayat 130 dan Al-Baqarah ayat 276. Ayat tersebut menjelaskan dalam syariah, imbalan dari modal tidak boleh berbentuk bunga karena bunga dianggap riba, sedangkan riba hukumnya haram.
\end{abstract}

Kata Kunci: Rasio Profitabilitas, UED-SP, Desa Kembung Luar, Perspektif Syariah.

\section{PENDAHULUAN}

Peraturan Daerah Kabupaten Bengkalis Nomor 03 Tahun 2005 Tentang Pembentuan Organisasi Dan Tata Kerja Dinas Pemberdaya Masyarakat Desa Kabupaten Bengkalis dikaitkan dengan pembentukan UED-SP dalam hal melakukan pemberdayaan keuangan masarakat Desa dan merupakan salah satu 
organisasi atau lembaga pemberdayaan masyarakat. Desa yang harus menjalankan fungsi umum, yakni: ${ }^{1}$

1. Pelaksanaan teknis pemberdayaan usaha ekonomi rakyat;

2. Membina bantuan pembangunan perkreditan dan pemasaran produksi;

3. Perumusan program ekonomi kerakyatan di pedesaan;

4. Pelaksanaan pengawasan terhadap program ekonomis kerakatan;

5. Pembinaan usaha ekonomi kerakyatan dengan upaya pemberian bantuan kepada masarakat sesuai dengan kewenangannya;

6. Melaksanaaan tugas tugas yang diberikan oleh atasan;

Disisi lain, melalui Peraturan Bupati Bengkalis Nomor 52 Tahun 2011, Tentang Petunjuk Teknis Program Pemberdaya Desa Kabupaten Bengkalis juga merupakan peraturan yang menguatkan posisi program pemberdaya Desa di Bengkalis melalui didirikannya UED-SP sebagai salah satu program pemberdaya Desa Kembung Luar Kecamatan Bantan, Kabupaten Bengkalis. Kinerja UED-SP di Desa ini berlangsung berdasarkan petunjuk, visi dan misi Kabupaten Bengkalis serta dalam perkembangan UED-SP dilapangan juga berasas dari peraturan Bupati Bengkalis tersebut.

Dengan Demikian, berdirinya UED-SP yang berlandaskan peraturan Bupati diharapkan harus mampu mendorong perkembangannya perekonomian masyarakat desa sesuai dengan cita-cita yang tertera pada Peraturan Bupati tersebut, meningatkan dorongan berusaha bagi anggota masyarakat Desaagar berhasil rendah, meningatkan kebiasaan gotong royong serta diharapkan masarakat Desa agar gemar menabung secara tertib.

Dalam memperoleh dana ini dan memasarkan kredit ke masyarakat, Usaha Ekonomi Desa (UED) haruslah melakukan usaha-usaha untuk mendapatkannya. Salah satu langkah utama yang harus dilakukan oleh pihak Usaha Ekonomi Desa (UED) yaitu bagaimana menarik nasabah, karna nasabah merupakan sumber dan bagi Usaha Ekonomi Desa (UED).

Salah satu produk Usaha Ekonomi Desa (UED) Desa Kembung Luar adalah produk kredit pinjaman. Kredit pinjaman merupakan pembiayaan yang diberikan kepada sejumlah pelaku ekonomi mikro yang akan mengembangkan usahanya.

Laporan keuangan untuk pihak luar menyajikan suatu gambaran menyeluruh tentang kondisi keuangan dan hasil usaha suatu organisasi. Pihak manajemen memerlukan informasi akuntansi keuangan yang lebih rinci bahwa kekurangan informasi akuntansi dalam manajemen perusahaan dapat membahayakan operasional perusahaan. Kondisi keuangan yang memburuk dan kekurangan catatan akuntansi akan membatasi akses untuk memeperoleh informasi yang diperlukan, sehingga akan menyebabkan kegagalan perusahaan. Oleh karena itu, pengguna informasi akuntansi berpengaruh terhadap perencanaan dan pengendalian perusahaan. (Antonio 2006, 14)

Berbagai pihak memerlukan pemahaman yang lebih dalam atas laporan keuangan, khususnya keuangan UED-SP, dengan cara melakukan analisa. Salah satunya yang sering digunakan adalah analisa rasio. Analisis rasio keuangan memberikan gambaran tentang keadaan keuangan lembaga keuangan yang dapat diukur pada periode tertentu. Rasio keuangan memberikan informasi dalam

\footnotetext{
${ }^{1}$ Dokumentasi: UED-SP Desa Kembung Luar Tanggal 24 April 2018
} 
membuat kebijakan manajemen dan target dalam pencapaian kinerja keuangan lembaga keuangan. Tujuan pengukuran kinerja keuangan penting untuk diketahui karena pengukuran yang dilakukan dapat mempengaruhi perilaku pengambilan keputusan dalam perusahaan. (Harahap 2013, 297)

Menurut syariah, imbalan modal harus dalam bentuk keuntungan (profit). Oleh karna itu, modal tidak boleh dipinjamkan kepada pihak lain kecuali dipinjamkan tanpa bunga. Modal dapat menghasilkan bunga dalam bentuk bunga tetapi dalam bentuk keuntungan dengan cara mengunakan modal tersebut untuk bertransaksi jual beli (bai' atau sale) antara pemilik modal dengan pembeli.

Adapun tujuan penelitian ini adalah:

1. Untuk mengetahui bagaimana Rasio Profitabilitas pada Usaha Ekonomi Desa Simpan Pinjam (UED-SP) Desa Kembung Luar.

2. Untuk mengetahui apakah Rasio Profitabilitas pada Usaha Ekonomi Desa Simpan Pinjam (UED-SP) Desa Kembung Luar sudah sesuai dengan perspektif syari'ah.

\section{LANDASAN TEORITIS}

\section{Konsep Laporan Keuangan}

Laporan keuangan mengambarkan kondisi keuangan dan hasil usaha suatu perusahaan pada saat tertentu atau jangka waktu tertentu, Adapun jenis laporan keuangan yang lazim dikelola adalah: Neraca atau Laporan Laba/Rugi, hasil usaha, Laporan Arus Kas, Laporan Perusahaan Posisi Keuangan (Harahap 2013, 105).

Bagi para analis, Laporan keuangan adalah media yang paling penting untuk menilai prestasi dan ekonomis suatu perusahaan. Pada tahap pertama seorang analisis tidak akan mampu melakukan pengamatan langsung ke suatu perusahaan dan seandainya dilakukan. Oleh karna itu yang paling penting adalah media laporan keuangan, Laporan keuangan inilah yang menjadi media sarana informasi (screen) bagi analis dalam proses pengambilan keputusan (Harahap 2013, 105).

Bagi suatu perusahaan, penyajian laporan keuangan secara khusus merupakan salah satu tanggung jawab manajer keuangan hal ini sesuai dengan fungsi manager keuangan, yaitu: merencanakan, mencari, memanfaatkan dana dana perusahaan dan memaksimalkan nilai perusahaan (Kasmir 2012, 6).

Maksud laporan keuangan yang menunjukkan kondisi perusahaan saat ini adalah merupakan kondisi terkini. Kondisi perusahaan terkini adalah keadaan keuangan perusahaan pada tanggal tertentu (untuk neraca) dan periode tertentu (untuk laporan keuangan laba rugi). Biasanya laporan keuangan dibuat per periode, misalnya tiga bulan, atau enam bulan untuk kepentingan internal perusahaan. Sementara itu, dengan adanya laporan keuangan, dapat diketahui posisi perusahaan terkini setelah menganalisis laporan keuangan tersebut dianalisis. (Kasmir 2012, 7)

Jenis laporan keuangan utama dapat disebutkan sebagai berikut (Harahap 2013, 106):

1. Daftar Neraca Mengambarkan posisi keuangan perusahaan pada suatu tanggal tertentu 
2. Perhitungan Laba /Rugi yang mengambarkan jumlah hasil biaya dan Laba/Rugi perusahaan pada suatu periode tertentu

3. Laporan Sumber dan Pengunaan Dana, Di sini dimuat sumber dan pengeluaran perusahaan selama satu periode

4. Laporan Arus Kas. Di sini digambarkan sumber dan pengunaan kas dalam suatu periode

5. Laporan harga pokok produksi yang mengambarkan beberapa dan unsur apa saja yang diperhitungkan dalam harga pokok produksi suatu barang. Dalam hal tertentu harga pokok produksi (HPPd) inidisatukan dalam laporan keuangan harga pokok penjalan (HPPj).

$\mathrm{HPPj}=\mathrm{HPPd}+$ Persediaan Awal - Persediaan Barang Akhir.

6. Laporan Laba Ditahan, menjelaskan posisi laba ditahan yang tidak dibagikan kepada pemilik saham

7. Laporan Perubahan Modal, menjelaskna perubahan posisi modal baik saham dalam PT atau Model perusahaan perseroan

8. Dalam suatu kajian Laporan Kegiatan Keuangan Laporan ini mengambarkan transaksi laporan keuangan perusahaan yang mempengaruhi kas atau ekuivalen kas. Laporan ini jarang digunakan. Laporan ini merupakan rekomendasi Trunblood Committee Tahun 1974.

\section{Konsep Rasio Keuangan}

Rasio keuangan adalah angka yang diperoleh dari hasil perbandingan dari satu pos laporan keuangan dengan pos lain-nya yang mempunyai hubungan yang relevan dan signifikan (berarti). Misalnya antara utang dan modal, antara Kas dan Total Aset, antara Harga Pokok produksi dengan total mutu penjualan,dan sebagainya. Teknik ini sangat lazim digunakan para analisis keuangan. Rasio keuangan sangat penting dalam melakukan analisis terhadap kondisi keuangan perusahaan. Rasio keuangan itu bisa banyak sekali. (Harahap 2013, 297)

Untuk menilai kondisi keuangan dan prestasi perusahaan analisis perusahaan memerlukan beberapa tolak ukur. Tolak ukur yang sering dipakai adalah rasio atau indeks yang menghubungkan dua data keuangan yang satu dengan yang lainnya. Rasio menggambarkan suatu hubungan atau pertimbangan antara satu jumlah tertentu dengan jumlah yang lainnya, dan dengan menggunakan alat analisis berupa rasio ini akan dijelaskan atau memberi gambaran kepada penganalisis tentang baik atau buruknya keadaan atau posisi keuangan suatu perusahaan. (Nuruwael 2013)

Salah satu parameter untuk menilai tingkat kinerja keuangan perusahaan adalah rasio keuangan. Analisis rasio keuangan ini sangat membantu dalam menilai kekuatan dan kelemahan kinerja keuangan di masa lalu dan prospeknya di masa yang akan datang. Melalui analisis rasio juga dapat diukur apakah perusahaan dapat membayar kewajiban jangka pendeknya, apakah besarnya piutang pada perusahaan cukup rasional, sejauh mana efisiensi dan efektivitas pendayagunaan seluruh aktiva yang dimiliki perusahaan, serta bagaimana kemampuan perusahaan untuk memperoleh laba. (Sulistyowati 2015)

Analisis Rasio Keuangan merupakan perhitungan yang dirancang untuk membantu mengevaluasi laporan keuangan. Teknik dengan menggunakan rasio ini merupakan cara yang saat ini masih paling efektif dalam mengukur tingkat kinerja serta prestasi keuangan perusahaan. (Rhamadana 2016) 
Rasio keuangan ini hanya menyederhanakan informasi yang mengambarkan hubungan antara pos tertentu dengan pos lain-nya. Dengan penyederhanaan ini kita dapat menilai secara cepat hubungan antara pos tadi dan dapat membandingkannya dengan rasio lain sehingga kita dapat memperoleh informasi dan memberikan penilaian. (Rhamadana 2016, 297)

Cara penggunaan rasio keuangan dapat menyederhanakan informasi yang menggambarkan hubungan antara pos tertentu dengan pos lainnya. Oleh karena itu, penggunaan rasio keuangan ditekankan pada pengukuran rasio profitabilitas dimana angka setelah rasio dihitung maka langkah berikutnya adalah menganalisa kinerja keuangan perusahaan dari angka-angka rasio tersebut. (Pongoh 2013)

Perbedaan jenis perusahaan dapat menimbulkan perbedaan rasio yang penting. Misalkan rasio ideal mengenai likuiditas untuk bank tidak sama dengan rasio pada perusahaan industri perdagangan, atau jasa. Oleh karenanya, di dalam laporan keuangan mengenai average industry ratio di Amerika perusahaan yang menerbitkan membagi-bagi rasio menurut jenis perusahaan bahkan menurut subsub industri yang lebih rinci. (Rhamadana 2016, 297-298)

Analisis rasio ini memiliki keunggulan dibandingkan teknik analisis lainnya. Keunggulan tersebut adalah (Rhamadana 2016, 298):

1. Rasio merupakan angka-angka atau ikhtisar statistik yang lebih mudah dibaca dan ditafsirkan;

2. Merupakan pengganti yang lebih sederhana dari informasi yang disajikan laporan keuangan yang sangat rinci dan rumit;

3. Mengetahui posisi perusahaan di tengah industri lain;

4. Sangat bermanfaat untuk bahan dalam mengisi model-model pengambilan keputusan dan model predikat(Z-score);

5. Menstandarisir saiz perusahaan;

6. Lebih mudah memperbandingkan perusahaan dengan perusahaan lain atau melihat perkembangan perusahaan secara periodic atau "time series".

7. Lebih mudah melihat tren perusahaan serta melakukan pre-diksi di masa yang akan datang.

Salah seorang penulis J. Courties memberikan kerangka rasio keuangan secara kategorik sebagai berikut (Rhamadana 2016, 300):

Gambar 1

Kerangka Rasio Keuangan Secara Kategori

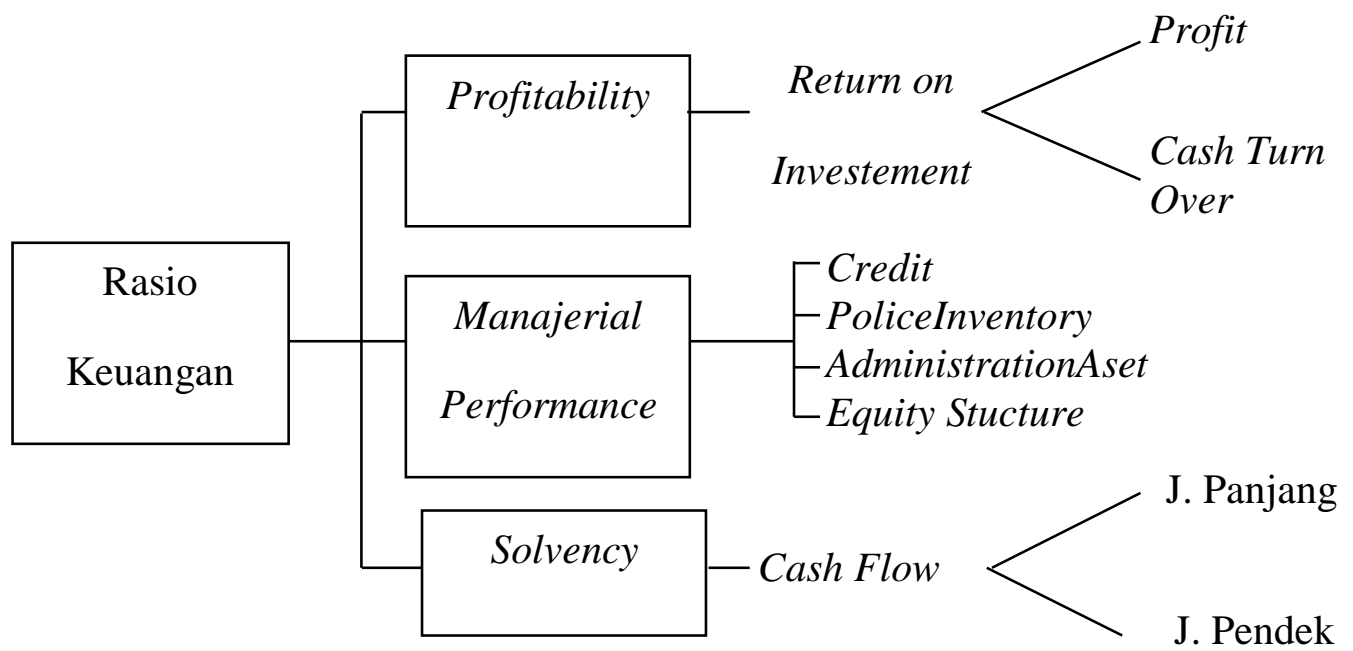


Courries melihat tiga aspek penting dalam menganalisis laporan keuangan yaitu sebagai berikut:

1. Profitabilitas Kemampuan perusahaan menghasilkan laba yang digambarkan oleh Return On Investment (ROI). Ia melihat ROI ini digambarkan lebih rinci lagi oleh Rasio Profit Margin dan Capital Turn Over.

2. Management Performance adalah rasio yang dapat menilai prestasi manajemen. Ia melihat dari segi kebijakan kredit, Persediaan, Administrasi, dan struktur Harta dan modal.

3. Solvency kemampuan perusahaan melunasi kewajibannya Solvency ini digambarkan oleh arus kas baik jangka pendek maupun jangka panjang.

Di samping Courties Dupont juga memiliki kerangka analisis yang lain. Dupont menganggap yang penting adalah ROI dan dari sini ia kembangkan rasio yang dapat menghubungan laporan neraca dan laporan keuangan laba/rugi. Adapun rasio keuangan yang sering digunakan adalah:

1. Rasio Likuiditas;

2. Rasio Solvabilitas;

3. Rasio Profitabilitas/Rentabilitas;

4. Rasio Levarage;

5. Rasio Pertumbuhan;

6. Market Based (Penilaian Pasar);

7. Rasio Produktivitas.

Rasio profitabilitas merupakan rasio untuk menilai kemampuan perusahaan dalam mencari keuntungan. Rasio ini juga memberikan ukuran tingkat efektivitas manajemen suat perusahaan. Hal ini ditunjukkan oleh laba yang dihasilkan dari penjualan dan pendapatan dan pendapatan investasi. Intinya adalah pengunaan rasio ini menunjukkan efisiensi perusahaan. Pengunaan rasio profitabilitas dapat dilakukan dengan mengunakan perbandingan antara berbagai komponen yang ada di laporan keuangan, terutama laporan keuangan neraca dan laporan laba rugi. Pengukuran dapat dilakukan untuk beberapa priode operasi. Tujuannya adalah agar terlihat berkembang perusahaan dalam rentan waktu tertentu, baik penurunan atau kenaikan, sekaligus mencari penyebab perubahan tersebut. (Kasmir 2012, 196)

Dalam praktinya, jenis-jenis rasio profitabilitas yang dapat digunakan adalah (Kasmir 2012, 199):

1. Profit Margin (Profit Margin On Sales)

Profit margin on sales atau Ratio Profit Margin atau margin laba atas penjualan merupakan salah satu rasio yang digunakan untuk mengukur margin laba atas penjualan. Cara pengukur rasio ini adalah dengan membandingkan laba bersih setelah pajak dengan penjualan bersih. Rasio ini juga dikenal dengan nama profit margin.Terdpat dua rumus untuk mencari profit magrin, yaitu sebagai berikut.

a. Untuk margin laba kotor dengan rumus:

\begin{tabular}{|c|c|}
\hline $\begin{array}{c}\text { Profit margin } \\
\text { (profit margin on sales) }\end{array}$ & $=$ Penjualan bersih - harga pokok penjualan \\
sales
\end{tabular}


b. Untuk margin laba bersih dengan rumus:

\begin{tabular}{|cc|}
\hline $\begin{array}{c}\text { Net Profit margin } \\
\text { (profit margin on sales) }\end{array}$ & $=\frac{\text { earning after interest and tax }}{\text { sales }}$ \\
\hline
\end{tabular}

2. Return On Invesment (ROI)

Hasil pengembalian investasi atau lebih dikenal dengan nama Return On Invesmen (ROI) atau Return on Total Asset merupakan rasio yang menunjukkan hasil (return) atas jumlah aktiva yang digunakan dalam perusahaan. ROI juga merupakan suatu ukuran tentang efektivitas manajemen dalam mengelola investasinya. Disamping itu, hasil pengembalian investasi menunjukkan produktivitas dari seluruh dana perusahaan, baik modal pinjaman maupun modal sendiri. Semakin kecil (rendah) rasio ini, semakin kurang baik, demikian pula sebaliknya. Artinya rasio ini digunakan untuk mengukur efektivitas dari keseluruhan operasi perusahaan. Rumus untuk mencari Return On Investment dapat digunakan sebagai berikut:

Return on Investment $(\mathrm{ROI})=$ Earning After Interest And Tax

Total Assets

Return On Invesment $20 \%$ berarti setiap Rp. 1 miliar menghasilkan keuntungan Rp.0,2 untuk semua investor. Nilai ROI yang semangkin mendekati 1, berarti semankin baik profitabilitas perusahaan karna setiapaktiva yang ada dapat menghasilkan laba. Jika mendekati 0 maka tidak baik untuk perusahaan.

3. Return On Equity (ROE).

Hasil pengembalian ekuitas atau return on equity atau rentabilitas modal sendiri merupakan rasio untuk mengukur laba bersih sesudah pajak dengan modal sendiri. Rasio ini menunjukan efisiensi pengunaan modal sendiri. Semakin tinggi rasio ini, semakin baik. Artinya posisi pemilik perusahaan semakin kuat, demikian pula sebaliknya.Rumus untuk mencari return on equity (ROI) dapat digunakan sebagai berikut:

Return on Equity $(\mathrm{ROE})=\underline{\text { Earning After interest and tax }}$ Equity

Jika hasil perhitungan ROE mendekati 1 menunjukkan semakin Efektif dan efisien penggunaan ekuitas perusahaan untuk menghasilkan pendapatan, demikian sebaliknya jika ROE mendekati 0 berarti perusahaan tidak mampu menghasilkan modal yang tersedia secara efisiensi untuk menghasilkan pendapatan. (Natalia)

\section{Konsep Profitabilitas Dalam Perspektif Islam}

Sebagai seorang Muslim yang mengimani Allah SWT Sang Pencipta Yang Maha Pengatur segala kehidupan kita didunia, wajib pula kita mengimani apa yang terdapat dalam Al-Qur'an. Allah SWT telah menciptakan Islam sebagai agama yang sempurna, dengan adanya Al-Qur'an sebagai Kalamullah dan sebagai pedoman hidup kita didunia tanpa keraguan didalamnya (Pratama 2018). Seperti yang tercantum dalam QS. An-Nahl ayat 89 (Kemenag RI 2005): 


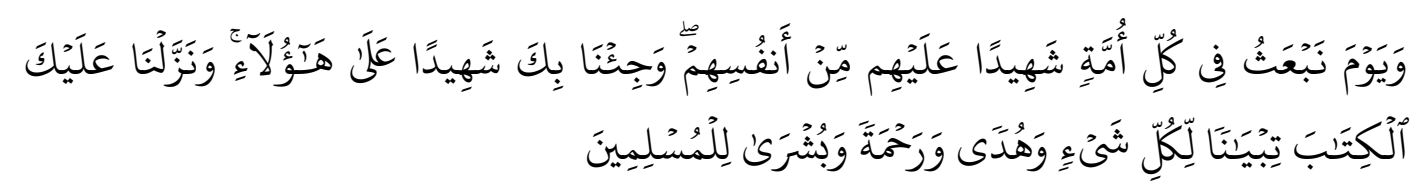

Artinya: "Dan (ingatlah) akan hari (ketika) Kami bangkitkan pada tiap-tiap umat seorang saksi atas mereka dari mereka sendiri dan Kami datangkan kamu (Muhammad) menjadi saksi atas seluruh umat manusia. Dan Kami turunkan kepadamu AlKitab (Al Qur'an) untuk menjelaskan segala sesuatu dan petunjuk serta rahmat dan kabar gembira bagi orang-orang yang berserah diri (muslim)".

Para informan berpendapat bahwa profitabilitas dalam Islam merupakan profit yang dicapai dengan tujuan atau orientasi yang sama, yaitu akhirat. Untuk mencapai tujuan akhirat tersebut tentu kita membutuhkan jalan yang harus dilalui, yang dimaksud dengan jalan sesuai yang diperintahkan oleh Allah SWT. Sudah menjadi kewajiban bagi setiap Muslim untuk mengikuti firman Allah SWT dan Sabda Rasul-Nya. Karena sesungguhnya setiap kehidupan kita di dunia sudah ada yang mengaturnya. Profitabilitas dalam perspektif Islam yang berpedoman pada Al-Qur'an dan Hadist, menjadi suatu acuan kita dalam mencapai sebuah tujuan profitabilitas tanpa meninggalkan orientasi akhirat. Banyak makna lain, selain keuntungan angka atau pun materil. Karena sesungguhnya angka ataupun materil tersebut hanya merupakan suatu alat guna mencapai tujuan akhirat tersebut. Untuk lebih jelasnya bagaimana profitabilitas dalam Islam, berikut ini adalah pemaparan berdasarkan apa yang diutarakan oleh para informan. (Pratama 2018)

\section{Tabel 1}

\section{Perbandingan Profitabilitas, Kapitalisme dan Islam}

\begin{tabular}{|c|c|c|c|}
\hline No & Konsep Profitabilitas & Konsep Kapitalis & Perspektif Islam \\
\hline 1 & $\begin{array}{l}\text { Latar belakang adanya } \\
\text { profit }\end{array}$ & $\begin{array}{l}\text { Sebagai suatu } \\
\text { kemampuan mendapat } \\
\text { laba }\end{array}$ & $\begin{array}{l}\text { Sebagai suatu } \\
\text { pencapaian } \\
\text { keberkahan dan } \\
\text { keridaan Allah SWT }\end{array}$ \\
\hline 2 & Penyajian profitabilitas & $\begin{array}{l}\text { Memaksimalkan profit } \\
\text { berupa angka }\end{array}$ & $\begin{array}{l}\text { Sesuai syariah Allah } \\
\text { SWT }\end{array}$ \\
\hline 3 & $\begin{array}{l}\text { Yang menemukan } \\
\text { konsep profitabilitas }\end{array}$ & Pendapat para ahli & $\begin{array}{l}\text { Allah SWT melalui } \\
\text { Al-Qur'an }\end{array}$ \\
\hline 4 & $\begin{array}{l}\text { Mekanisme } \\
\text { perhitungan } \\
\text { profitabilitas }\end{array}$ & $\begin{array}{l}\text { Menggunakan rumus } \\
\text { perhitungan }\end{array}$ & Intangible \\
\hline 5 & $\begin{array}{l}\text { Profitabilitas dalam hal } \\
\text { kemaslahatan }\end{array}$ & $\begin{array}{l}\text { Tidak memperhatikan } \\
\text { kemaslahatan bersama, } \\
\text { hanya untuk kekayaan } \\
\text { pribadi atau sekelompok }\end{array}$ & $\begin{array}{l}\text { Memperhatikan } \\
\text { kemaslahatan bagi } \\
\text { bersama }\end{array}$ \\
\hline 6 & $\begin{array}{l}\text { Kegunaan } \\
\text { profitabilitas }\end{array}$ & $\begin{array}{l}\text { Sebagai penumpuk } \\
\text { kekayaan di dunia }\end{array}$ & $\begin{array}{l}\text { Sebagai alat untuk } \\
\text { beribadah }\end{array}$ \\
\hline 7 & $\begin{array}{l}\text { Redistribusi } \\
\text { profitabilitas }\end{array}$ & CSR & ZISWAF \\
\hline 8 & $\begin{array}{l}\text { Cara mencapai } \\
\text { profitabilitas }\end{array}$ & $\begin{array}{l}\text { Menghalalkan segala } \\
\text { cara }\end{array}$ & $\begin{array}{l}\text { Ada rambu-rambu } \\
\text { yang tidak boleh }\end{array}$ \\
\hline
\end{tabular}




\begin{tabular}{|c|l|l|l|}
\hline & & & $\begin{array}{l}\text { diterjang, berorientasi } \\
\text { akhirat dan ada } \\
\text { saluran kebawahnya }\end{array}$ \\
\hline 9 & $\begin{array}{l}\text { Sudut pendang } \\
\text { terhadap profitabilitas }\end{array}$ & Hanya maten & $\begin{array}{l}\text { Materi dan } \\
\text { keberkahan }\end{array}$ \\
\hline
\end{tabular}

Ekonomi islam yang didasarkan pada prinsip syariah tidak mengenal konsep bunga karna menurut islam bunga adalah riba yang haram (terlarang) hukumnya. Artinya, bisnis dalam islam yang didasarkan pada prinsip syariah tidak mengenal pembedaan bunga oleh pemilik modal atau investor atau kreditur atas pengunaan uang yang dipinjamkan oleh kreditur (pemilk modal atau investor) kepada debitur (peminjam uang). (Sjahdeini 2014, 157)

Dalam syariah, imbalan dari modal (capital) tidak boleh berbentuk (interest) karena bunga dianggap riba yang hukumnya haram menurut syariah. Menurut syariah, imbalan modal harus dalam bentuk keuntungan (profit). Oleh karna itu, modal tidak boleh dipinjamkan kepada pihak lain kecuali dipinjamkan tanpa bunga. Modal dapat menghasilkan bunga dalam bentuk bunga tetapi dalam bentuk keuntungan dengan cara mengunakan modal tersebut untuk bertransaksi jual beli (bai' atau sale) antara pemilik modal dengan pembeli (Sjahdeini 2014, 158). Allah SWT. berfirman dalam Surah Ali-'Imran ayat 130 (Kemenag RI 2005):

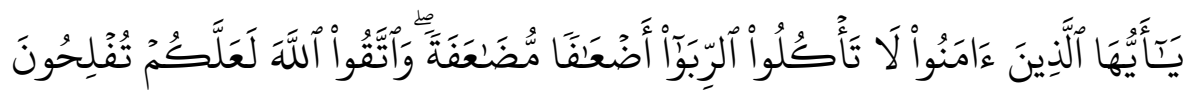

Artinya: "Wahai orang-orang yang beriman! Janganlah kamu memakan riba dengan berlipat ganda dan bertakwalah kepada Allah agar kamu beruntung."

Kemudian Allah SWT. juga berfirman dalam Surah Al-Baqarah ayat 276 (Kemenag RI 2005):

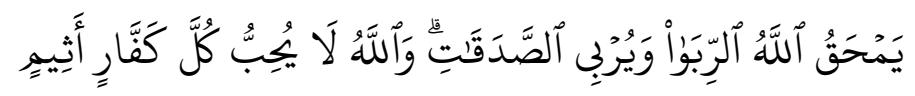

Artinya: "Allah memusnahkan riba dan menyuburkan sedekah. Allah tidak menyukai setiap orang yang tetap dalam kekafiran dan bergelimang dosa”.

\section{HASIL DAN PEMBAHASAN}

\section{Penyajian Data}

Berdirinya lembaga keuangan masyarakat Usaha Ekonomi Desa Kembung Luar memiliki peran penting untuk mendorong usaha bagi masyarakat desa yang berpenghasilan rendah serta meningkatkan peran masyarakat dalam mengelola Usaha Ekonomi Desa. Dalam rangka pemberdayaan masyarakat khususnya terhadap para pelaku ekonomi mikro dan kecil di pedesaan, agar usaha yang dikelola lebih efisien dan memiliki daya saing maka diperlukan adanya fasilitas kreditan yang dekat dengan masyarakat serta dengan persyaratan yang tidak memberatkan masyarakat kecil pedesaan. Usaha Ekonomi Desa Simpan Pinjam (UED-SP) menjadi salah satu faktor yang memegang peranan penting karena berfungsi sebagai lembaga penghimpun dan penyalur dana. Pemberian pinjaman modal untuk masyarakat berdampak positif dalam membantu kesulitan untuk mengembangkan usaha yang dijalankan. Sebelum realisasi pinjaman dilaksanakan, 
pengelola Usaha Ekonomi Desa Simpan Pinjam (UED-SP) haruslah mampu mengestimasikan kelancaran pengembalian pinjaman dan pembayaran bunganya atau kebijakan pemberian pinjaman. Disamping itu perlu dilakukan penelitian terhadap kelayakan usaha calon debitur untuk mengetahui besarnya pendapatan atau penghasilan agar Usaha Ekonomi Desa Simpan Pinjam (UED-SP) dapat terhindar atau menekankan sekecil mungkin terjadinya resiko pinjaman macet. ${ }^{2}$

Berdasarkan Petunjuk Teknis No 38 Tahun 2014 dijelaskan bahwa laporan UED-SP terdiri dari laporan bulanan, laporan insidental dan laporan tahunan. Laporan bulanan merupakan laporan rutin yang disampaikan setiap bulan oleh masing-masing jenjang tugas sesuai dengan alur pelaporan yang meliputi kondisi keuangan dan kondisi program. ${ }^{3}$

Laporan insidental bersifat khusus, mendesak atau kasualistik serta dibuat diluar mekanisme laporan reguler,sedangkan laporan tahunan di buat pada setiap akhir tahun kegiatan, selain itu laporan tahunan merupakan rekapitulasi perkembangan kegiatan dan analisis manfaat dan dampak program serta dilengkapi dengan hasil kajian dan inovasi yang dilakukan selama priode kegiatan. Laporan tahunan disampaikan paling lambat 1 bulan berakhir priode pelaksanaan kegiatan. Ketua pengelola kegiatan dan keuangan kepada kepala Desa/kelurahan dengan tembusan kepada pendamping Desa,setiap bulannya disampaikan pada akhir bulan berjalan. Laporan keuangan UED/K-SP meliputi: ${ }^{4}$

1. Laporan keuangan lengkap 2016-2018

2. Laporan perkembangan pinjaman dan pengembalian

3. Laporan permasalahan yang dihadapi dan langkah penanganan

4. Copy rekening Koran

5. Jumlah dan jenis usaha serta besarnya pinjaman

6. Jumlah kelompok dan anggota pemanfaat

7. Rencana kerja dan realisasi kegiatan UED-SP

8. Perkembangan kegiatan simpan pinjam anggota

9. Laporan lainnya sesuai kebutuhan

Pada akhir tahun pengelola UED -SP membuat laporan keuangan tahunan sebagai bentuk pertanggung jawaban pelaksanaan kegiatan tahunan kepada masyarakat.Berdasarkan petunjuk teknis yang ada, laporan keuangan UED-SP terdiri dari laporan harian, daftar uang masuk dan keluar,neraca dan laporan laba rugi.

Tabel 2

Rekapitulasi Laporan Keuangan UED-SP Desa Kembung Luar

\begin{tabular}{|c|c|c|c|}
\hline Tahun & \multicolumn{1}{|c|}{$\begin{array}{c}\text { Laba Setelah } \\
\text { Bunga dan Pajak }\end{array}$} & Total Aset & Equity \\
\hline 2016 & $\mathrm{Rp} 79.851 .618,00$ & $\mathrm{Rp} \mathrm{1.188.879.025,00}$ & $\mathrm{Rp} \mathrm{93.926.860,00}$ \\
\hline 2017 & $\mathrm{Rp} 75.529 .120,00$ & $\mathrm{Rp} \mathrm{1.869.444.355,00}$ & $\mathrm{Rp} \mathrm{106.997.980,00}$ \\
\hline 2018 & $\mathrm{Rp} \mathrm{102.022.331,00}$ & $\mathrm{Rp} \mathrm{1.596.127.900,00}$ & $\mathrm{Rp} \mathrm{143.359.311,00}$ \\
\hline
\end{tabular}

Berikut Rasio profitabilitas di UED-SP Desa Kembung Luar:

${ }^{2}$ Wawancara: Bapak Supriadi (ketua UED-SP Sukses Usaha Mandiri), UED-SP Desa Kembung Luar Tanggal 24 April 2018.

${ }^{3}$ Ibid, Tanggal 24 April 2018.

${ }^{4}$ Ibid, Tanggal 24 April 2018. 
a. Return on Investment.

Hasil pengembalian investasi atau lebih dikenal dengan nama Return on Investment (ROI) atau return on total assets merupakan rasio yang menunjukkan hasil (return) atau jumlah aktiva yang digunakan dalam perusahaan. ROI juga merupakan suatu ukuran tentang efektivitas manajemen dalam mengelola investasinya.

Di samping, hasil pengembalian investasi menunjukkan produktifitas dari seluruh dana perusahaan, baik modal pinjaman maupun modal sendiri. Semakin kecil (rendah) rasio ini, semakin kurang baik, demikian sebaliknya. Artinya rasio ini digunakan untuk mengukur efektifitas dari keseluruhan operasi perusahaan.

Nilai ROI yang semakin mendekati 1 , berarti semankin baik profitabilitas perusahaan karna setiap aktiva yang ada dapat menghasilkan laba. Jika mendekati 0 maka tidak baik untuk perusahaan.

Berikut ini nilai Return on Investment pada Usaha Ekonomi Desa Simpan Pinjam (UED-SP) tahun 2016:

$$
\begin{aligned}
\text { Return on Investment } & =\frac{\text { Earning After Interest And Tax }}{\text { Total Assets }} \\
& =\frac{\text { Rp. } 79.851 .618,00}{\mathrm{Rp} .1 .188 .879 .025,00} \\
& =0,067(6,7 \%)
\end{aligned}
$$

Berikut ini nilai Return on Investment pada Usaha Ekonomi Desa Simpan Pinjam (UED-SP) tahun 2017:

$$
\begin{aligned}
\text { Return on Investment } & =\frac{\text { Earning After Interest And Tax }}{\text { Total Assets }} \\
& =\frac{\text { Rp. } \quad 75.529 .120,00}{\text { Rp. } 1.869 .444 .355,00} \\
& =0,04(4 \%)
\end{aligned}
$$

Berikut ini nilai Return on Investment pada Usaha Ekonomi Desa Simpan Pinjam (UED-SP) tahun 2018:

$$
\begin{aligned}
\text { Return on Investment } & =\frac{\text { Earning After Interest And Tax }}{\text { Total Assets }} \\
& =\frac{\text { Rp. } 102.022 .331,00}{\text { Rp. } 1.596 .127 .900,00} \\
& =0,064(6,4 \%)
\end{aligned}
$$

b. Return On Equity.

Hasil pengembalian equitas atau Return On Equityatau rentabilitas modal sendiri merupakan rasio untuk mengukur laba bersih sesudah pajak dengan modal sendiri. Rasio ini menunjukkan efisiensi pengguaan modal sendiri. semakin tinggi rasio ini, semakin baik. Artinya posisi pemilik perusahaan semakin kuat, demikian pula sebaliknya.

Jika hasil perhitungan ROE mendekati 1 menunjukkan semakin Efektif dan efisien penggunaan ekuitas perusahaan untuk menghasilkan pendapatan, demikian sebaliknya jika ROE mendekati 0 berarti perusahaan tidak mampu menghasilkan modal yang tersedia secara efisiensi untuk menghasilkan pendapatan. 
Berikut ini nilai Return On Equitypada Usaha Ekonomi Desa Simpan Pinjam (UED-SP) tahun 2016:

$$
\begin{aligned}
\text { Return On Equity } & =\frac{\text { Earning After Interest And Tax }}{\text { Equity }} \\
& =\frac{\text { Rp. } 79.851 .618,00}{\text { Rp. 93.926.860,00 }} \\
& =0.85(85 \%)
\end{aligned}
$$

Berikut ini nilai Return On Equitypada Usaha Ekonomi Desa Simpan Pinjam (UED-SP) tahun 2017:

$$
\begin{aligned}
\text { Return On Equity } & =\frac{\text { Earning After Interest And Tax }}{\text { Equity }} \\
& =\frac{\text { Rp. } 75.529 .120,00}{\text { Rp. } 106.997 .980,00} \\
& =0.705(70,5 \%)
\end{aligned}
$$

Berikut ini nilai Return On Equitypada Usaha Ekonomi Desa Simpan Pinjam (UED-SP) tahun 2018:

$$
\begin{aligned}
\text { Return On Equity } & =\frac{\text { Earning After Interest And Tax }}{\text { Equity }} \\
& =\frac{\text { Rp. } 102.022 .331,00}{\text { Rp. } 143.359 .311,00} \\
& =0.711(71,1 \%)
\end{aligned}
$$

\section{Analisis Rasio Profitabilitas pada Usaha Ekonomi Desa Simpan Pinjam (UED-SP) Desa Kembung Luar Tahun 2016-2018}

Berdasarkan penyajian data yang dipaparkan sebelumnya, maka dapat dijelaskan bahwa laporan keuangan UED-SP Desa Kembung Luar terdiri dari laporan kas harian, daftar uang masuk dan uang keluar, neraca percobaan, laporan laba rugi, dan laporan pendapatan dan biaya.

Rasio keuangan yang dihitung berdasarkan gabungan dari beberapa unit yang ada. Dengan demikian dapat dikatakan bahwa berdasarkan data hasil rasio yang dihitung oleh Badan Usaha Milik Desa yang ada di Desa Kembung Luar maka rasio yang digunakan dalam kelangsungan unit-unit yang termasuk UED-SP adalah rasio profitabilitas.

Berdasarkan rasio keuangan yang ada di UED-SP Desa Kembung Luar, dapat disimpulkan bahwa Return on Investment dan Return On Equity UED-SP Desa Kembung Luar adalah sebagai berikut:

Tabel 3

Perkembangan Rasio Profitabilitas UED-SP Desa Kembung Luar

\begin{tabular}{|l|l|c|c|c|}
\hline \multirow{2}{*}{ No } & \multirow{2}{*}{ Rasio Profitabilitas } & \multicolumn{3}{|c|}{ Tahun } \\
\cline { 3 - 5 } & & $\mathbf{2 0 1 6}$ & $\mathbf{2 0 1 7}$ & $\mathbf{2 0 1 8}$ \\
\hline 1 & Return On Invesment & $0,067(6,7 \%)$ & $0,04(4 \%)$ & $0,064(6,4 \%)$ \\
\hline 2 & Return On Equity & $0,85(85 \%)$ & $0,705(70,5 \%)$ & $0,711(71 \%)$ \\
\hline
\end{tabular}

Sumber: data olahan peneliti 
Berdasarkan Tabel 3 di atas, diketahui bahwa tingkat rasio profitabilitas UED-SP Desa Kembung Luar tahun 2016-2018 dihitung dengan dua rasio yaitu Return On Invesment, dan Return On Equity. Masing-masing rasio mengalami penurunan danpeningkatan dari tahun 2016-2018. Hal ini berarti tingkat pengembalian hutang oleh nasabah UED-SP belum sesuai dengan yang diharapkan dengan regulasi dana yang tidak tetap dan tingkat pengembalian hutangnya tidak normal.

Dari hasil perhitungan, maka dapat dilihat bahwa ROI tahun 2016 sebesar 0,067 (6,7\%), tahun 2017 sebesar 0,04 (4\%), dan tahun 2018 sebesar 0,064 (6,4\%). Tahun 2016-2017 ROI mengalami penurunan karena perputaran aset dan laba bersih dalam satu tahun menurun. Hal ini menunjukkan kemampuan UED-SP dalam menghasilkan laba bersih dari aset belum maksimal. Tahun 2017-2018 mengalami peningkatan karena laba yang dihasilkan pada tahun 2017-2018 meningkat. ROI yang dimiliki UED-SP Desa Kembung Luar cukup baik. Dari hasil Return On Invesment mendekati angka 1 sehingga dapat diketahui bahwa UED-SP ini sudah baik profitabilitasnya karena setiap aktiva yang ada dapat menghasilkan laba.

Begitu juga dari hasil perhitungan Return On Equity, maka dapat dilihat ROE tahun 2016 sebesar 0,85 (85\%), tahun 2017 sebesar 0,705 (70,5\%), dan tahun 2018 sebesar 0,711 (71\%). Dari hasil tersebut dapat ditunjukkan bahwa pada UED ini dalam mengelola modal dalam menghasilkan keuntungan netto mengalami penurunan pada tahun 2016-2018 dan mengalami peningkatan di tahun 2016-2018. Dilihat dari tiga tahun terakhir tersebut UED belum maksimal mengelola modal dalam menghasilkan keuntungan. ROE yang dimiliki UED-SP Desa Kembung Luar dalam keadaan baik. Dari hasil ROE yang diperoleh pada tahun 2016-2018 mendekati angka satu maka menunjukkan UED ini sehat, penggunaan Equitas UED untuk menghasilkan pendapatan bagus.

Adapun yang menyebabkan terjadinya penurunan dan peningkatan yaitu rendahnya minat masyarakat dalam mengembangkan usaha dan adanya nasabah yang telat dalam pembayaran pinjaman kredit sehingga pinjaman menjadi macet.

\section{Analisis Rasio Profitabilitas Pada Usaha Ekonomi Desa Simpan Pinjam (UED-SP) Desa Kembung Luar Di Tinjau Dari Perspektif Syariah}

Berdasarkan penyajian data diatas dapat penulis analisa bahwa rasio profitabilitas pada UED-SP Desa Kembung luar tidak sesuai dengan prinsip syariah. Ketidaksesuaian tersebut disesuaikan dalam fiman Allah dalam QS. Ali'Imran ayat 130 dan Al-Baqarah ayat 276. Ayat tersebut menjelaskan bahwa dalam syariah, imbalan dari modal (capital) tidak boleh berbentuk bunga (interest) karena bunga dianggap riba, sedangkan riba akan dimusnahkan Allah SWT dan hukumnya haram. Profitablitas ataupun keuntungan hanyalah sebuah kelebihan dari modal. Untuk mencapai profitabilitas yang Islami harus diawali dengan modal yang Islami pula. Berawal dari modal Islami tersebut, seperti: membangun jaringan sebagai modal silaturahmi, keakraban, saling percaya, saling jujur dan hal baik lainnya akan menghasilkan profit tanpa meninggalkan orientasi akhirat seperti yang dijelaskan pada QS. An-Nahl ayat 89. 


\section{KESIMPULAN DAN SARAN}

Dari hasi penelitian yang penulis lakukan serta didukung dengan teori yang telah penuls pelajari dan pembahasan yang penuls lakukan sebelumnya. Maka penulis dapaat memberi kesimpulan bahwa:

1. Rasio Profitabilitas mengalami penurunan dan peningkatan dari tahun 20162018. Dari hasil perhitungan, Tahun 2016-2017 ROI mengalami penurunan karena perputaran aset dan laba bersih dalam satu tahun menurun. Hal ini menunjukkan kemampuan UED-SP dalam menghasilkan laba bersih dari aset belum maksimal. Tahun 2017-2018 mengalami peningkatan karena laba yang dihasilkan pada tahun 2017-2018 meningkat. Begitu juga dari hasil perhitungan Return On Equity, maka dapat dilihat ROE tahun 2016 sebesar $0,85(85 \%)$, tahun 2017 sebesar 0,705 (70,5\%), dan tahun 2018 sebesar 0,711 (71\%). Dari hasil tersebut dapat ditunjukkan bahwa pada UED ini dalam mengelola modal dalam menghasilkan keuntungan netto mengalami penurunan pada tahun 2016-2018 dan mengalami peningkatan di tahun 20162018.

2. Rasio profitabilitas pada UED-SP Desa Kembung luar tidak sesuai dengan prinsip syariah karena terdapat bunga. Ketidaksesuaian tersebut disesuaikan firman Allah SWT dalam QS. Ali-'Imran ayat 130 dan Al-Baqarah ayat 276. Ayat tersebut menjelaskan bahwa dalam syariah, imbalan dari modal (capital) tidak boleh berbentuk bunga (interest) karna bunga dianggap riba, sedangkan riba hukumnya haram.

Saran penulis bagi pihak UED-SP Desa Kembung Luar adalah:

1. Diharapkan dapat meningkatkan kinerja pengelola dalam memberikan pinjaman untuk lebih meminimalisir terjadinya kredit macet dan memperbanyak sosialisasi kepada masyarakat, agar masyarakat tahu tujuan dan fungsi dari UED-SP Desa Kembung Luar itu sendiri.

2. Memberikan bimbingan serta arahan kepada pemanfaat untuk memanfaatkan dana pinjaman dengan baik dan benar agar dapat mencapai tujuan dari UEDSP Desa Kembung Luar sendiri, yaitu untuk memberdayakan masyarakat menengah kebawah dalam pengembangan usaha.

3. Sebaiknya UED-SP Desa Kembung Luar sebaiknya menerapkan transaksi berbasis syariah, karena Islam tidak boleh berbentuk bunga (interest) karena bunga dianggap riba, sedangkan riba akan dimusnahkan Allah SWT dan hukumnya haram.

\section{DAFTAR PUSTAKA}

Al-Haryono, Jusup. 2011. Dasar-Dasar Akuntansi, Jilid 1 Edisi Ketujuh. Yogyakarta: YKPN.

Al-Musahamah, Muhammad dan Isma'il, Nur Ghofar. 2004. Akuntansi Syariah. Yogyakarta: Al Muhasamah, Pesantren Mahasiswa Ekonomi Islam.

Antonio, Muhammad Syafi'i. 2006. Bank Syariah, Dari Teori Ke Praktik. Jakarta: Gema Insani.

Departemen Pendidikan Nasional. 2002. Kamus Besar Bahasa Indonesia. Jakarta: PT Balai Pustaka. 
Harahap, Sofyan Syafri. 2013. Analisi Kritis Atas Laporan Keuangan. Jakarta: Rajawali Pers.

Kasmir. 2012. Analisis Laporan Keuangan. Jakarta: Rajawali Pers.

Kementerian Agama Republik Indonesia. 2005. Al-Qur'an Dan Terjemahan. Surabaya: PT. Insan Media Pustaka.

Natalia, Desy dan Samben, Rande dan Musviyanti. "Analisis Rasio Likuiditas, Rasio Solvabilitas Dan Rasio Profitabilitas Untuk Mengukur Kinerja Keuangan Pada PT. KUD Kopta Unit Tambang Di Samarinda”. https://www.academia.edu/6087934/Analisis_Rasio_Likuiditas_Rasio_Sol vabilitas_Dan_Rasio_Profitabilitas_Untuk_Mengukur.

Nurhayati, Sri dan Wasilah. 2012. Akuntansi Syariah Di Indonesia. Edisi 2 Revisi. Jakarta: Salemba Empat.

Nuruwael, Grace Monica dan Sitohang, Sonang. 2013. “Analisis Rasio Keuangan Sebagai Alat Untuk Menilai Kinerja Keuangan PT. International Nickel Corporation Tbk.”. Jurnal Ilmu \& Riset Manajemen, Vol. 2 No. 1.

Pongoh, Marsel. 2013. "Analisis Laporan Keuangan Untuk Menilai Kinerja Keuangan PT. Bumi Resources Tbk.”. JURNAL EMBA: Jurnal Riset Ekonomi, Manajemen, Bisnis Dan Akuntansi, Vol.1 No.3.

Pratama, Putri dan Jaharuddin . 2018. "Rekonstruksi Konsep Profitabilitas Dalam Perspektif Islam", IKRA-ITH HUMANIORA: Jurnal Sosial dan Humaniora, Vol.2, No.1, Maret 2018.

Renyowijoyo, Muindro. 2013. Akuntansi Sektor Publik. Organisasi Non Laba. Edisi 3. Jakarta: Mitra Wacara Media.

Rhamadana, Recly Bima dan Triyonowati. 2016. "Analisis Rasio Keuangan Untuk Menilai Kinerja Keuangan Pada PT. HM. Sampoerna Tbk.”. Jurnal Ilmu dan Riset Manajemen, Vol.5, No.7.

Sisbintari, Ika. 2012. "Analisis Komparatif CAR, LDR, ROA, DAN ROE Sebelum Dan Sesudah Merger Pada PT. Bank CIMB Niaga Tbk". PROFIT: Jurnal Administrasi Bisnis, Vol. 6, No.2.

Sjahdeini, Sutan Remy. 2014. Perbankan Syariah. Produk-Produk Dan AspekAspek Hukumnya, Edisi Pertama. Jakarta: Kencana.

Sugiyono. 2010. Metode Penelitian Bisnis. Bandung: Alfabeta.

Sujarwani, Wiratna. 2015. Akuntansi Sektor Publik. Teori, Sonsep, Dan Praktik. Yogyakarta: Pustaka Baru.

Sulistyowati, Nur Wahyuning. 2015. “Analisis Laporan Keuangan Sebagai Alat Untuk Menilai Kinerja Keuangan PT. Pelabuhan Indonesia III Surabaya". ASSET: Jurnal Akuntansi dan Pendidikan, Vol.4, No.2.Suwardjono. 2005. Teori Akuntansi, Edisi Ketiga. Yogyakarta: BPFE.

Triyuwono, Iwan. 2012. Akuntansi Syariah. Perspektif, Metodologi Dan Teori. Jakarta: Rajawali Pers.

Ulum, Ihyaul. 2004. Akuntansi Sektor Publik. Sebuah Pengantar. Malang: Universitas Muhammadiyah Malang. 